\title{
PENGARUH PENDIDIKAN MATEMATIKA REALISTIK INDONESIA (PMRI) TERHADAP PEMAHAMAN KONSEP DAN BERPIKIR LOGIS SISWA
}

\section{THE EFFECTS OF REALISTIC MATHEMATICS EDUCATION INDONESIA (PMRI) ON UNDERSTANDING CONCEPTS AND LOGICAL THINKING STUDENTS}

\author{
Nur Sri Widyastuti, Pratiwi Pujiastuti \\ SD Tahunan Yogyakarta, Universitas Negeri Yogyakarta \\ widyastutinursri85@gmail.com, pratiwiuny@yahoo.co.id
}

\begin{abstract}
Abstrak
Penelitian ini bertujuan untuk (1) mengetahui pengaruh penggunaan Pendidikan Matematika Realistik Indonesia (PMRI) dan Direct Instruction (DI) dalam pembelajaran matematika materi jarak dan kecepatan terhadap: pemahaman konsep dan berpikir logis Siswa, (2) mengetahui pengaruh positif pembelajaran matematika dengan PMRI terhadap pemahaman konsep siswa, dan (3) mendeskripsikan pengaruh positif pembelajaran matematika dengan PMRI terhadap berpikir logis. Populasi penelitian adalah siswa kelas V segugus II Kecamatan Umbulharjo dengan sampel 3 sekolah dengan subjek penelitian 91 siswa. Instrumen yang digunakan adalah tes pemahaman konsep dan berpikir logis awal maupun akhir. Analisis data yang digunakan adalah uji multivariat of covariance (MANCOVA), kemudian dilanjutkan dengan independent sample t-test dengan taraf signifikansi 0,05. Hasil penelitian ini menunjukkan bahwa: (1) terdapat pengaruh yang signifikan antara pembelajaran matematika dengan PMRI dan DI dalam pembelajaran matematika materi jarak dan kecepatan terhadap pemahaman konsep dan berpikir logis siswa, (2) terdapat pengaruh positif pembelajaran matematika dengan PMRI terhadap pemahaman konsep siswa daripada Direct Instruction (DI), dan (3) terdapat pengaruh positif pembelajaran matematika dengan PMRI terhadap berpikir logis siswa daripada Direct Instruction (DI) bagi siswa kelas V Sekolah Dasar segugus II Kecamatan Umbulharjo Kota Yogyakarta.
\end{abstract}

Kata Kunci: pembelajaran matematika, PMRI, direct instruction, pemahaman konsep, berpikir logis

\begin{abstract}
This research aimed to (1) know the effect of the use of Realistic Mathematics Education in Indonesia (PMRI) and Direct Instruction (DI) on the subject of distance and speed of the: Understanding the concept and Logical Thinking students, (2) know the positive influence effect of the use of Realistic Mathematics Education in Indonesia (PMRI) of the Understanding the concept, and (3) describe the positive influence effect of the use of Realistic Mathematics Education in Indonesia (PMRI) of the logical thingking students. The population of the study was students in the V class group 2 District of Umbulharjo with sampling selected three classes using with 91 subject students. Class experiments were treated using PMRI learning and classroom learning control with Direct Instruction (DI). Data collection techniques used are testing techniques to determine the ability of Understanding Concepts and Logical Thinking students on the subject of distance and speed after treatment. The data analysis technique used is the multivariate test of covariance (MANCOVA), followed by independent sample t-test with a significance level of 0.05 . The results of this study indicate that (1) there are significant differences in the learning of mathematics with PMRI and DI in mathematics learning material to distance and speed of the: understanding of the concept and logical thinking students, (2) Learning math using PMRI gives more positive effect on the understanding concepts of students rather than using Direct Instruction, and (3) Learning math using PMRI gives more positive effect on the logical thinking of students rather than using Direct Instruction for Fifth Grade Group 2 Elementary School Umbulharjo District of Yogyakarta.
\end{abstract}

Keywords: mathematics learning, PMRI, direct instruction, understanding concepts, logical thinking 


\section{Pendahuluan}

Matematika merupakan ilmu dasar yang mendasari perkembangan ilmu-ilmu lain. Oleh karena itu matematika menjadi salah satu mata pelajaran yang penting untuk diajarkan di sekolah. Ungkapan 'Mathematics for life' and 'mathematics as a human activities' yang diutarakan oleh Freudethal mengartikan bahwa matematika merupakan sebuah aktivitas yang berlaku dan bermanfaat dalam kehidupan sehari-hari. Setiap aktivitas manusia dalam kehidupan sehari-hari tidak lepas dari peran matematika.

Pada umumnya tujuan pembelajaran matematika adalah membentuk kemampuan bernalar siswa yang terukur dalam berfikir kritis, berfikir logis, kreatif, inovatif, pemecahan masalah, bersikap obyektif baik dibidang matematika itu sendiri ataupun bidang lain dalam kehidupan sehari-hari. Sedangkan pendidikan matematika di sekolah dasar pada hakekatnya adalah memberikan pengalaman belajar terhadap anak dalam hal bermatematika sesuai dengan tahapan perkembangannya. Selain dari yang disebutkan di atas dengan mempelajari matematika siswa juga dapat memiliki sikapsikap terpuji seperti teliti, cermat, hemat, jujur, tegas, bertanggungjawab, pantang menyerah dan percaya diri (Fathani, 2009, pp.99-102).

Sebagai ilmu dasar, dalam mempelajari matematika khususnya di tingkat sekolah dasar perlu memahami kondisi psikologis siswa. Tahapan perkembangan berfikir pada usia SD masih berada dalam tahapan berfikir konkrit sehingga memerlukan langkah-langkah untuk dapat memahami sesuatu hal yang sifatnya abstrak. Menurut Piaget tahapan perkembangan anak siswa SD yang masuk pada usia 7-12 tahun berada dalam tahap operasional konkret, dimana siswa mulai dapat berfikir secara logis terhadap objek konkrit, meninggalkan sifat egosentrisnya, mampu berfikir, belajar, mengingat, dan berkomunikasi. Hal tersebut menunjukkan bahwa dengan pengalaman yang diperoleh diharapkan siswa dapat mengurutkan, mengklasifikasikan, berkomunikasi dan menggunakan simbol-simbol serta konsep dalam matematika. Dengan demikian melalui pengalaman nyata siswa dapat mempertajam penguasaan konsep dalam upaya meningkatkan kemampuan berpikir, daya nalarnya untuk dapat menyelesaikan permasalahan yang dihadapi dalam kehidupan sehari-hari.
Pemahaman konsep merupakan kemampuan siswa dalam menguasai suatu konsep/materi yang terindikasi dalam ranah kognitif. Dengan memahami suatu konsep siswa dapat mengetahui, menjelaskan, mendeskripsikan, membandingkan, membedakan, menggolongkan, memberikan contoh dan bukan contoh, menyimpulkan dan mengungkapkan kembali suatu objek dengan bahasanya sendiri dengan menyadari proses-proses yang dilaluinya. Dalam pembelajaran matematika di kelas, seringkali kurang menanamkan kemampuan berfikir sehingga siswa masih belum sepenuhnya memahami konsep seutuhnya.

Kecenderungan pembelajaran matematika hanya pada menghafal rumus dan menerapkannya untuk menyelesaikan soal dirasa kurang menguntungkan siswa, karena akan kesulitan dalam menghadapi persoalan yang memerlukan pemecahan masalah. Pemahaman konsep merupakan pondasi dasar bagi siswa untuk mngembangkan ketrampilan dan kemampuan berfikir lainnya seperti kemampuan berfikir logis. Hal ini yang menjadi dasar pentingnya pemahaman konsep dalam pembelajaran matematika.

Siswa yang telah memahami konsep dengan benar akan terlatih dan mampu mengembangkan kemampuan berfikir logis untuk dapat menyelesaikan permasalahan sehari-hari. Kemampuan berfikir logis atau berfikir rasional merupakan kemampuan befikir yang perlu dikembangkan untuk mengoptimalkan perkembangan otak kiri. Kemampuan berfikir logis ini sangat diperlukan untuk menyelesaikan permasalahan matematis ataupun dalam kehidupan sehari-hari. Kemampuan berfikir logis merupakan kemampuan berfikir siswa untuk menarik kesimpulan yang sah menurut aturan logika. Salah satu contoh berpikir logis pada tingkat sekolah dasar adalah dapat membuat kesimpulan dan membuktikan kesimpulan itu benar atau tidak sesuai dengan pengalaman yang telah diperoleh oleh siswa sebelumnya. Pemahaman konsep dan kemampuan berfikir logis memerlukan suatu pengetahuan dari pengalaman oleh siswa sendiri. Oleh karena itu diperlukan peran dan usaha guru untuk memotivasi, melatih dan menggali segala kemampuan dan pengetahuan siswa.

Pengetahuan dan kemampuan bukan merupakan hasil transfer ilmu dari seseorang ke orang lain dalam hal ini guru ke siswa, akan tetapi pengetahuan dan kemampuan dibentuk sendiri oleh siswa melalui pengalaman nyata 
dengan mengaitkan pengetahuan yang telah dimilikinya. Dalam pembelajaran matematika di sekolah dasar tentunya juga harus mengutamakan pengalaman, sehingga mau tidak mau harus melibatkan siswa secara aktif. Dengan begitu akan terjadi komunikasi efektif dua arah antara siswa dan guru, dimana dampak pengiringnya siswa dapat mengembangkan pemahaman dalam matematika dan ketrampilannya seperti berfikir logis, kreatifitas, kerjasama dan pemecahan masalah. Hal ini mengacu pada paradigma belajar sesuai dengan paham konstruktivisme yang merupakan suatu faham bahwa pengetahuan yang kita miliki merupakan hasil dari konstruksi kita sendiri. Pergeseran paradigma pembelajaran dari teacher centered menjadi student centered menjadi landasan dalam pembenahan pembelajaran. Selain itu hal yang perlu diperhatikan adalah prinsip-prinsip pembelajaran diantaranya adalah berpusat pada siswa, belajar sambil melakukan (learning by doing), mengembangkan keingintahuan dan belajar sepanjang hayat (life long education) (Depdiknas, 2003).

Kenyataan yang terjadi bahwa pendidikan di Indonesia masih mengalami berbagai persoalan. Hal ini berimbas kepada rendahnya kualitas pendidikan itu sendiri. Dibandingkan dengan negara lain di dunia bahkan di Asia, pendidikan di Indonesia khususnya dalam bidang matematika dan sains termasuk dalam kategori rendah. Berdasarkan hasil riset yang dilakukan oleh Progam for International Student Assessment (PISA) tahun 2006 menunjukkan bahwa kemampuan siswa-siswa Indonesia dalam bidang matematika dan sains cenderung terpuruk dimana menempati peringkat 50 dari 57 negara dengan skor 391. Sedangkan menurut hasil studi Trends in International Mathematics and Science (TIMSS) tahun 2007 prestasi Indonesia menempati urutan 36 dengan skor rata-rata 405 dari 49 negara dengan skor ratarata internasional 500 (Tjalla, 2010, pp.7-14). Sementara itu, berdasarkan hasil studi PISA dan TIMSS pada tahun 2011 menunjukkan tidak ada perubahan bahkan cenderung terjadi penurunan. Menurut hasil studi TIMSS menunjukkan Indonesia berada di peringkat 38 dari 42 negara. Penilaian TIMSS ini menekankan pada penguasaan konsep. Sementara penilaian dari PISA yang menekankan pada aspek penerapan dalam kehidupan sehari-hari justru merosot dengan menempati peringkat kedua dari bawah, yaitu peringkat 64 dari 65 negara.
Hal tersebut didukung dengan kenyataan yang terjadi dilapangan, beradasarkan hasil pengamatan diperoleh hasil bahwa (1) aktivitas siswa lebih banyak mendengarkan penjelasan guru dalam mengikuti pembelajaran khususnya matematika. Di sini terlihat bahwa aktivitas guru lebih dominan. Jelas terlihat bahwa siswa hanya aktif dalam hal mencatat. Dengan guru berperan sebagai subjek pembelajaran, komunikasi antara guru dan siswa berjalan kurang efektif. (2) pembelajaran matematika lebih difokuskan pada hasil yaitu nilai daripada proses pembelajaran. Hal ini terlihat bahwa setelah guru menjelaskan secara singkat langkah-langkah penyelesaian soal kemudian diberikan soalsoal latihan untuk dikerjakan. (3) pembelajaran seringkali tidak melibatkan siswa secara langsung dalam mengkonstruksi pengetahuan. Hal ini terlihat bahwa dalam pembelajaran guru lebih berperan sebagai subjek, siswa menerima hasil pembelajaran yang sudah jadi bukan menemukan dan mengkonstruksi pengetahuan mereka sendiri untuk menemukan konsep yang dipelajari. (4) pada saat pembelajaran jarang terlihat terjadi komunikasi efektif dua arah antara guru dan siswa. Hal ini terlihat dengan sering diamnya siswa dan tidak mengajukan pertanyaan ataupun mengemukan pendapat mereka kepada guru. Bahkan sebagian besar dari siswa merasa sungkan untuk mengungkapkan pendapat mereka. dan (5) metode atau pendekatan yang digunakan lebih banyak menggunakan ceramah dan latihan soal. Hal ini menunjukkan bahwa pembelajaran matematika dirasakan siswa kurang menarik bagi siswa.

Salah satu pendekatan yang memerlukan inovasi dan kreatifitas guru untuk melibatkan peran aktif siswa adalah Pendidikan Matematika Realistik Indonesia (PMRI). PMRI ini dilakukan dengan mengaitkan hal nyata/ real sebagai pengalaman siswa. Pendekatan pembelajaran ini sangat cocok diterapkan pada pembelajaran matematika karena dalam mempelajari matematika tidak cukup hanya mengetahui dan menghafal, tetapi juga dibutuhkan suatu pemahaman serta kemampuan menyelesaikan persoalan matematika dengan baik dan benar melalui benda-benda real/nyata dalam kehidupan sehari-hari sebagai pengalaman siswa. Pendekatan ini merupakan adaptasi dari pendekatan Realistic Mathematics Education (RME) yang dikembangkan di Belanda oleh Freudenthal. PMRI merupakan pendekatan pembelajaran yang menekankan aktivitas insani, dalam 
pembelajarannya digunakan konteks yang sesuai dengan situasi di Indonesia.

Pembelajaran matematika dengan PMRI merupakan aktivitas belajar yang mengaitkan dengan kehidupan nyata siswa dalam kegiatan sehari-hari. Dasar filosofi yang digunakan dalam PMRI adalah pembelajaran bermakna/meaningfull learning dan kontruktivisme. Dalam pembelajaran ini siswa mengaitkan pengetahuan lama yang dimiliki dalam memahami suatu konsep matematika siswa membangun sendiri pemahaman dan pengertiannya. Karakteristik dari pendekatan ini adalah memberikan kesempatan seluas-luasnya kepada siswa untuk mengkonstruksi atau membangun pemahaman dan pengertiannya tentang konsep yang baru dipelajarinya. PMRI adalah pendekatan pembelajaran yang bertitik tolak dari hal-hal yang "real" bagi siswa, menekankan "proses of doing mathematics", berdiskusi berkolaborasi berargumentasi dengan teman sekelas untuk menemukan sendiri dan pada akhirnya menggunakan matematika itu untuk menyelesaikan masalah baik secara individu maupun kelompok. Ciri-ciri pembelajaran dengan PMRI dikutib oleh Supinah (2008, p.16) sebagai berikut: (1) menggunakan masalah kontekstual, (2) menggunakan model, (3) menggunakan hasil dan konstruksi siswa sendiri, (4) berfokus pada siswa, dan (5) terjadi interaksi antara guru dan siswa.

PMRI merupakan sebuah adaptasi dari Realistic Mathematics Education (RME) yang disesuaikan dengan konteks relistik di Indonesia. Dengan kata lain landasan filosofi PMRI adalah sama dengan RME. Menurut Sembiring, Hadi \& Dolk (2008, p 928) bahwa PMRI dikembangkan tidak hanya untuk menerapkan cara baru pengajaran dan belajar matematika tetapi juga untuk mencapai transformasi sosial di Indonesia. Jadi ciri khas PMRI adalah penggunaan situasi nyata/realitas yang ada dikembangkan sesuai dengan konteks dan keadaan di Indonesia.

Sementara itu, RME merupakan teori pembelajaran matematika yang dikembangkan oleh Fruedenthal di Belanda yang memandang bahwa matematika sebagai suatu aktivitas. Dengan demikian, aktivitas yang dimaksud dalam matematika merupakan aktivitas manusia yang meliputi aktivitas pemecahan masalah, mencari masalah dan mengorganisasi pokok persoalan. Sejalan dengan hal tersebut Van den HeuvelPanhuizen (1996, pp.13-14) menjelaskan bahwa mengajar matematika memerlukan konteks yang realistis. Dengan menggunakan model dan konteks, siswa dapat melewati proses matematisasi dan mengembangkannya dalam dirinya sendiri. Dengan demikian dengan inti dari pembelajaran matematika adalah dapat menggunakannya untuk menyelesaikan permasalahan sehari-hari. Sementara itu menurut Freudenthal, 'students should be given the opportunity to experience a similar process as the one which the mathematical concept' dalam Bustang et. al., (2013, p.60). Artinya siswa harus diberi kesempatan untuk mengalami proses yang sama dalam konsep matematika. Hal ini berarti bahwa proses pembelajaran harus dilakukan dengan kegiatan yang memungkinkan siswa untuk melakukan proses. Proses tersebut merupakan proses dimana siswa dapat menemukan konsep dalam matematika.

Hal ini sejalan dengan konsep yang dikemukakan oleh Treffers dalam Fauzan (2002, pp.33-34) dalam pembelajaran RME, yaitu

The key idea of RME is that children should be given the opportunity to reinvent mathematics under the guidance of an adult (teacher). In addition, the formal mathematical knowledge can be developed from children's informal knowledge.

Dalam ungkapannya tersebut, Treffers menjelaskan ide kunci dari pembelajaran matematika realistik yang menekankan perlunya kesempatan bagi siswa untuk menemukan kembali matematika dengan bantuan orang dewasa (guru). Selain itu disebutkan pula bahwa pengetahuan matematika formal dapat dikembangkan (ditemukan kembali) berdasar pengetahuan informal yang dimiliki siswa.

Pernyataan-pernyataan yang dikemukakan tersebut menjelaskan suatu cara pandang terhadap pembelajaran matamatika yang ditempatkan sebagai suatu proses bagi siswa untuk menemukan sendiri pengetahuan matematika berdasar pengetahuan informal yang dimilikinya. Dengan demikian memahami matematika harus dipelajari oleh siswa dari hal yang mudah dipahami dan sudah diketahui siswa. Hal ini sejalan dengan pernyataan Dickinson \& Hough (2012, p.1) bahwa pembelajaran matematika harus dikembangkan oleh siswa dengan konteks yang masuk akal menurut mereka. Dengan demikian menurut pandangan ini matematika disajikan bukan sebagai barang "jadi" dan "instan" yang dapat dipindahkan oleh guru ke 
dalam pikiran siswa dengan cepat tetapi diperoleh melalui sebuah proses berpikir siswa.

Dalam pembelajaran matematika menggunakan pendekatan PMRI siswa mempelajari konsep matematika melalui hal nyata terlebih dahulu sebelum memasuki hal yang abstrak. Melalui hal nyata tentang apa yang dilihat, dikenal dan diketahui oleh siswa memiliki peran pangkal sebagi titik mula pembelajaran dalam melakukan aktivitas matematisasi. Treffers dalam Rasmussen et. al. (2005, pp.1-2) dan Freudenthal dalam Panhuizen (1996, p.11) menyebutkan dalam pembelajaran matematika dengan RME terdapat dua jenis matematisasi yaitu matematisasi horisontal dan vertikal, dengan penjelasan seperti berikut ini "Horizontal mathematization involves going from the world of life into the world of symbol, while vertical mathematization means moving within the world of symbol". Pernyataan tersebut menjelaskan bahwa matematisasi horisontal menyangkut proses transformasi masalah nyata/ sehari-hari ke dalam bentuk simbol. Matematisasi horizontal mencakup situasi masalah, dimana tergantung pada latar belakang dan pengalaman masing-masing individu. Dengan demikian sangat memungkinkan bahwa situasi masalah setiap individu akan berbeda. Contoh matematisasi horisontal adalah pengidentifikasian, perumusan dan pemvisualisasian masalah dengan cara-cara yang berbeda oleh siswa.

Sedangkan matematisasi vertikal merupakan proses yang terjadi dalam lingkup simbol matematika itu sendiri. Sedangkan contoh matematisasi vertikal adalah presentasi hubunganhubungan dalam rumus, menghaluskan dan menyesuaikan model matematika, penggunaan model-model yang berbeda, perumusan model matematika dan penggeneralisasian. Dengan matematisasi siswa mengkonstruksi konsep matematika ke dalam struktur kognitif melalui penemuan terbimbing. Disinilah yang menjadi ruhnya pembelajaran PMRI dimana prinsip utamanya adalah penemuan terbimbing dan matematisasi progresif. Mengacu kepada dua jenis kegiatan matematisasi tersebut de Lange dalam Fauzan (2002, p.41) mengidentifikasi empat pendekatan yang dipakai dalam mengajarkan matematika yaitu pendekatan mekanistik, empiristik, strukturalistik dan realistik. Pengkategorian keempat pendekatan tersebut didasarkan pada penekanan atau keberadaan dua aspek matematisasi (horisontal atau vertikal).
Esensi lain pembelajaran matematika realistik adalah tiga prinsip kunci yang dapat dijadikan dasar dalam merancang pembelajaran. Menurut Gravemeijer dalam zulkardi, (2002, p.29) bahwa dalam RME memiliki prinsipprinsip sebagai berikut: (1) Guided reinventation and progressive mathematizing (penemuan terbimbing dan matematisasi progessif); (2) Didactical phenomenology (fenomenologi didaktis); (3) Self-developed models (model yg berkembang sendiri)

Dari ketiga prinsip tersebut Gravemeijer mengembangkan tingkatan model PMR menjadi 4 dalam Zandiech \& Rasmussen (2010, p.58) dan Zulkardi (2002, p.31) yang digambarkan sebagai berikut.

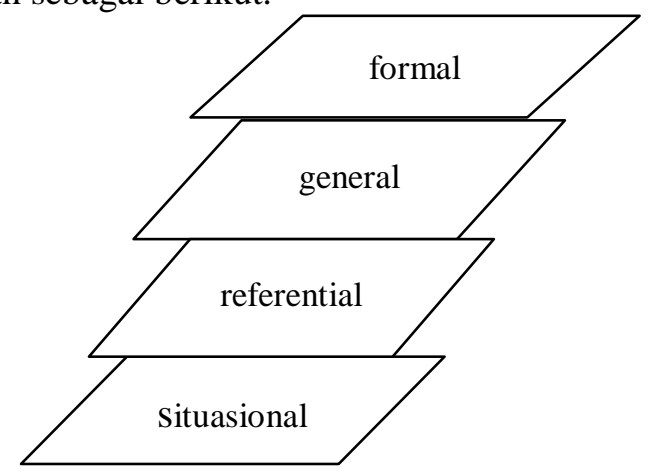

Gambar 1. Tingkatan model PMR

Keempat tingkatan tersebut adalah situation (situasi), model of (model dari), model for (model untuk), formal mathematics (matematika formal). Titik awal mula pembelajaran PMRI yang haruslah berangkat dari hal yang nyata bagi siswa sehingga dapat mendorong siswa untuk terpaut dengan situasi tersebut. Inilah yang menjadi karakteristik dalam PMRI. Hal yang serupa dituturkan oleh De Lange dalam Fauzan, (2002, p.44) dan Gravemeijer dalam Zulkardi (2002, p.29) bahwa RME memiliki 5 karakteristik dari RME antara lain: (1) the use of real-life contexts/penggunaan masalah kontekstual, (2) the use of use models/ penggunaan model sebagai jembatan, (3) student's free production/penggunaan kontribusi dan kreativitas siswa, (4) interaction/interaktivitas, dan (5) intertwining/keterkaitan.

Sementara itu mengacu pada karakteristik RME, Sembiring merinci karakteristik PMRI menjadi 3 yaitu siswa lebih aktif, konteks dan bahan ajar terkait langsung dengan lingkungan sekolah dan siswa, dan peran guru lebih aktif dalam merancang bahan ajar dan kegiatan kelas.

Mendasarkan pada kondisi kelas seperti uraian di atas serta beberapa karakteristik dan 
prinsip pembelajaran matematika realistik, maka langkah-langkah pembelajaran yang dilaksanakan dalam penelitian ini terdiri atas: (a) Langkah pertama. Memahami masalah kontekstual; (b) Langkah kedua. Menjelaskan masalah kontekstual; (c) Langkah ketiga. Menyelesaikan masalah kontekstual; (d) Langkah keempat. Membandingkan dan mendiskusikan jawaban; (e) Langkah-5. Menyimpulkan

Beberapa penelitian yang mengupas tentang PMRI yang menyatakan bahwa PMRI berpengaruh terhadap kemampuan berpikir, kognitif siswa, hasil belajar dan prestasi belajar siswa. Penelitian RME/ PMR berbasis budaya terhadap kemampuan berpikir kritis matematis dan karakter siswa dilakukan oleh Somakin (2011) dengan subjek penelitian siswa SMP di Indonesia pada level sekolah tinggi, sedang dan rendah, menemukan bahwa kemampuan berpikir kritis matematis pada siswa SMP dapat ditingkatkan dengan baik dengan menggunakan PMRI dibandingkan dengan siswa yang mengikuti pembelajaran matematika biasa (PMB) dan terdapat interaksi antara pendekatan (PMR dan PMB) dan level sekolah (tinggi, rendah, sedang) terhadap peningkatan kemampuan berpikir kritis siswa. Sementara hasil penelitian dari Ai Nani Nurhayati dan Maulana(2009) menyebutkan bahwa penerapan Pendidikan Matematika Realistik mampu memotivasi dan menarik perhatian siswa. Selain itu dari hasil penelitian dengan Pendidikan Matematika Realistik juga dapat menanamkan konsep operasi perkalian dan pembagian bilangan bulat dngan tingkat penguasaan cukup baik bagi siswa kelas IV SD negeri Cipanas Tanjungkerta Sumedang, mampu memotivasi dan minat siswa dalam belajar matematika, dan lebih membuat siswa aktif dalam mengikuti pembelajaran matematika.

Penelitian tentang pengaruh PMRI terhadap kemampuan pemecahan masalah juga dilakukan oleh Muchlis (2012) di SD Kartika 1.10 Padang. Dalam penelitiannya dihasilkan bahwa kemampuan pemecahan masalah siswa dengan pembelajaran PMRI lebih baik daripada dengan pembelajaran konvensional. Hal ini dapat dilihat dari kemampuan siswa dalam memaknai soal dan menentukan penyelesaiannya, siswa mampu menyelesaikan soal secara prosedural, siswa mampu menjelaskan proses dalam penyelesaian masalah, dan dapat meyelesaikannya dengan tepat. Penelitian lain yang dilakukan oleh Fauzan dan Yerizon (2013) terhadap RME menemukan bahwa melalui dengan RME dapat memberikan pengaruh lebih baik dalam meningkatkan kemampuan pemecahan masalah dan penalaran siswa dibandingkan dengan pembelajaran konvensional. Hal lain yang ditemukan bahwa pada siswa dengan kemandirian belajar sedang dan rendah RME juga memberikan pengaruh lebih baik.

Penelitian lain tentang RME yang dilakukan oleh Sugiman dan Yaya S. Kusumah di tingkat Sekolah Menengah Pertama Kota Yogyakarta pada tahun 2010. Dalam penelitiannya menemukan dampak RME terhadap peningkatan kemampuan pemecahan masalah bagi siswa SMP. Dalam penelitiannya diperoleh hasil bahwa dengan RME kemampuan pemecahan masalah matematik siswa yang diajar dengan PMR lebih tinggi daripada siswa yang diajar dengan pembelajaran biasa.

Penelitian tentang PMRI juga dilakukan oleh Bustang et all (2013) yang dilakukan pada 43 siswa SD di Palembang. Penelitian ini tentang pengembangan teori Instruksi local dalam pembelajaran konsep segitiga melalui visual kegiatan lapangan dan representasi tata ruang. Dalam penelitian ini dihasilkan bahwa dengan PMRI siswa dapat mengingat dari hasil pengalaman mereka dalam aktivitas visual tetapi belum secara bisa secara otomatis memahami secara abstrak tentang konsep segitiga. Penemuan lain bahwa melalui aktivitas interaksi sosial siswa dapat proses belajar matematika.

\section{Metode Penelitian}

Penelitian ini merupakan penelitian quasi eksperimen dengan Penelitian ini merupakan penelitian kuasi eksperimen dengan model kelompok kontrol non-ekuivalen. Populasi penelitian adalah siswa SD kelas V di Gugus II Kecamatan Umbulharjo Kota Yogyakarta. Dari keenam sekolah dipilih 3 sekolah dengan purposive random sampling yaitu SD N Golo, SD N Tahunan dan SD Muh Sukonandi. Untuk kelas eksperimen menggunakan pembelajaran PMRI yaitu SD Golo dan SD Tahunan sedangkan kelas kontrol menggunakan DI di SD Muh Sukonandi.

Untuk mengukur peningkatan kemampuan pemahaman konsep dan berpikir logis digunakan instrumen berupa soal uraian yang terdiri atas 5 soal dan digunakan sebagai pretest dan posttest. Adapun reliabilitas instrumen dihitung dengan menggunakan rumus Alpha Cronbach dan diperoleh sebesar 0,8. Analisis data digunakan analisis statistik inferensial dengan analisis multivariate of kovarian. 


\section{Hasil Penelitian dan Pembahasan}

Hasil analisis statistik deskriptif data tersebut menunjukkan perbedaan hasil pretes siswa dalam PK antara kelas kontrol dan kelas eksperimen. Pada perolehan skor PK pada hasil pretes, dari 30 siswa pada kelas Eksperimen 1 terdapat 19 siswa atau $63 \%$ nya yang PK awalnya berada pada kategori sangat rendah dan sisanya sebanyak 11 siswa atau $37 \%$ berada pada kategori rendah. Sementara itu skor ratarata PK_awal dari kelas eksperimen 1 sebesar 10,65 dengan kategori sangat rendah. PK kelas eksperimen 2 dengan jumlah 31 siswa, 14 siswa atau $47 \%$ diantaranya berada pada kategori sangat rendah dan 16 siswa atau 53\% memiliki kategori rendah. Dengan demikian pada kelas eksperimen 2, skor PK_awal memiliki rata-rata 11,48 dengan kategori sangat rendah. Sedangkan untuk 30 siswa di kelas kontrol terdapat 20 siswa atau $67 \%$ pada kategori sangat rendah dan 10 siswa atau 33\% pada kategori rendah, dengan skor rata-rata PK_awal memiliki ratarata 12,57 dengan kategori sangat rendah.

Dari hasil tersebut terlihat jelas bahwa untuk rata-rata skor PK_awal tertinggi terdapat pada kelas kontrol yaitu 12,57. Dengan demikian terdapat selisih rata-rata antara kelas kontrol dengan kelas eksperimen 1 memiliki pada saat pretes sebesar 1,92 dan selisih kelas eksperimen 2 dengan kelas kontrol sebesar 1,09. Namun demikian jika dilihat dari kategori perolehan skor PK_awal dari semua kelas berada pada kategori sangat rendah.

Sementara itu untuk rata-rata PK_akhir tertinggi adalah kelas eksperimen 2 memiliki PK rata-rata 34,65 dengan kategori sangat rendah, kelas eksperimen 1 memiliki PK ratarata 34,48 dengan kategori sangat rendah dan terendah adalah kelas kontrol yang memiliki PK rata-rata 29,93 dengan kategori sangat rendah. Selisih 4,72 lebih tinggi pada PK kelas eksperimen 2 dibandingkan dengan PK kelas kontrol dan PK kelas eksperimen 1 lebih tinggi 4,55 daripada PK kelas kontrol. Hal ini menunjukkan bahwa pada hasil posttest terhadap PK terdapat peningkatan baik di kelas eksperimen maupun di kelas kontrol. Rata-rata PK semua kelas berada pada kategori sedang, tetapi jika dilihat dari rata-rata dan peningkatan rata-rata kelas eksperimen lebih tinggi daripada kelas kontrol.

Untuk mempermudah perbandingan antara pretes dan posttest pada kelas kontrol, kelas eksperimen 1 dan kelas eksperimen 2 disajikan dalam grafik sebagai berikut:

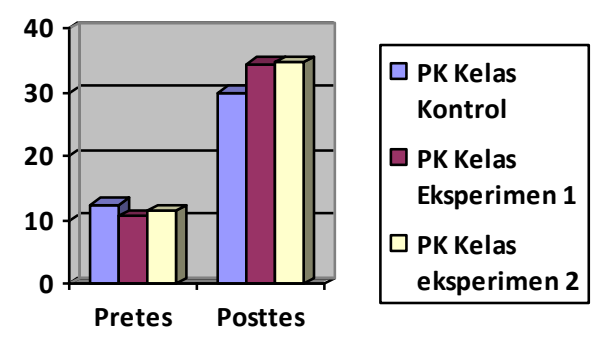

\section{Gambar 2. Perbandingan Pemahaman Konsep}

Sementara itu untuk hasil tes BL diperoleh pada hasil pretes, dari 30 siswa pada kelas Eksperimen 1 dan dan 31 siswa eksperimen 2 terdapat $100 \%$ siswa memiliki kemampuan BL sangat rendah. Sementara itu skor rata-rata kemampuan BL_awal siswa dari kelas eksperimen 1 sebesar 7,17 dengan kategori sangat rendah dan kelas eksperimen 2 adalah 7,74 dengan kategori sangat rendah. Sedangkan untuk 30 siswa di kelas kontrol terdapat 28 siswa atau 93\% pada kategori sangat rendah dan 2 siswa atau $7 \%$ pada kategori rendah, dengan skor ratarata kemampuan BL 9,17 dengan kategori sangat rendah. Meskipun ketiga kelas memiliki rata-rata skor BL yang berada pada kategori sangat rendah, akan tetapi berdasarkan hasil analsis statistik deskriptif data diatas menunjukkan adanya perbedaan. Hasil menunjukkan bahwa rata-rata pretes tertinggi terdapat pada kelas kontrol

Sementara untuk hasil posttes menunjukkan bahwa kemampuan BL siswa setelah mengalami perlakuan adalah sebagai berikut: dari 30 siswa pada kelas Eksperimen 1 terdapat 14 siswa atau sebesar $47 \%$ berada pada kategori rendah dan 26 siswa atau 53\% pada kategori sedang. Sedangkan dari 31 siswa di kelas eksperimen 2 terdapat 3 siswa atau $10 \%$ berada pada kategori rendah dan 27 siswa atau 20\% berada pada kategori sedang. Sedangkan untuk kelas kontrol yang terdiri dari 30 siswa terdapat 27 siswa atau 20\% diantaranya berada pada kategori rendah dan sisanya sebanyak 3 siswa atau $10 \%$ berada pada kategori sedang.

Sementara itu jika dilihat dari perolehan skor rata-rata kemampuan BL_awal siswa dari kelas eksperimen 1 sebesar 7,17 dengan kategori sangat rendah dan kelas eksperimen 2 adalah 7,74 dengan kategori sangat rendah. Sedangkan untuk 30 siswa di kelas kontrol terdapat 28 siswa atau $93 \%$ pada kategori 
sangat rendah dan 2 siswa atau $7 \%$ pada kategori rendah, dengan skor rata-rata kemampuan BL 9,17 dengan kategori sangat rendah. Meskipun ketiga kelas memiliki rata-rata skor BL yang berada pada kategori sangat rendah, akan tetapi berdasarkan hasil analsis statistik deskriptif data diatas menunjukkan adanya perbedaan. Hasil menunjukkan bahwa rata-rata pretes tertinggi terdapat pada kelas kontrol.

Sedangkan pada BL_akhir siswa dari hasil posttest dapat dilihat dari perolehan ratarata skor BL siswa dengan hasil tertinggi adalah kelas eksperimen 2 dengan rata-rata 31,45 memiliki kriteria sedang, kelas eksperimen 1 dengan rata-rata 30,57 kriteria sedang dan kelas kontrol memiliki rata-rata 26,23 dengan kriteria rendah. Dari hasil tersebut kelas eksperimen 2 dengan kelas kontrol memiliki selisih 5,22 dan selisih 4,34 antara kelas eksperimen 1 dengan kontrol. Sementara untuk postest kategori kelompok eksperimen meningkat pada kategori sedang dengan rata-rata 31,01 dan kelas kontrol rendah dengan rata-rata 26,23 sehingga terdapat selisih 4,78 antara kelas eksperimen dan kelas kontrol. Untuk mempermudah perbandingan antara pretes dan posttest pada kelas kontrol, kelas eksperimen 1 dan kelas eksperimen 2 disajikan dalam grafik sebagai berikut:

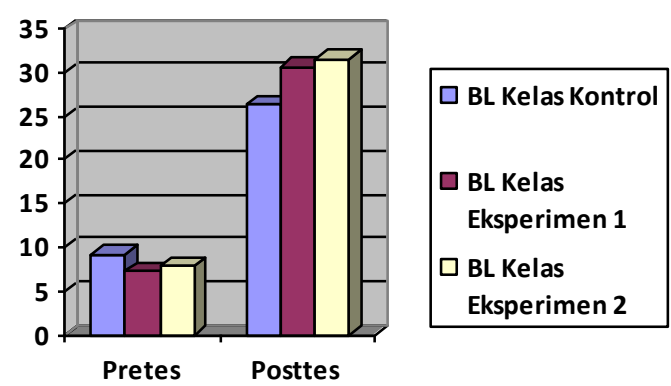

\section{Gambar 3. Perbandingan Berpikir Logis}

Hasil analisis selanjutnya adalah dengan uji mancova pada taraf kepercayaan 95\%. Dengan perhitungan secara multivariate telah diperoleh hasil yang menunjukkan bahwa terdapat pengaruh yang signifikan terhadap PK dan BL pada siswa kelas eksperimen dengan PMRI dibandingkan dengan kelas kontrol yang menggunakan pembelajaran DI. Hal ini terlihat hasil analisis data secara multivariate diperoleh nilai F pada wilk's lamda sebesar 49,706 dengan angka signifikansi 0,000. Sementara itu berdasarkan hasil pengujian secara individu pada pemahamn konsep dan juga BL menunjukkan hasil yang signifikan. Hal tersebut juga terlihat dari uji lanjut yang dilakukan dan deskripsi data yang menggambarkan adanya perbedaan yang signifikan dari nilai rata-rata siswa yang mengikuti pembelajaran antara PMRI dan DI.

Secara keseluruhan, PK dan BL siswa pada kelas eksperimen yang menggunakan pendekatan pembelajaran PMRI lebih tinggi dibandingkan dengan yang menggunakan pembelajaran DI. Hal tersebut dapat terlihat dari perbandingan rerata dari $\mathrm{PK}$ dan $\mathrm{BL}$ antara kelas eksperimen dan kontrol. Rerata PK pada kelas eksperimen dengan PMRI lebih tinggi sebesar 4,63 atau $15 \%$ dibandingkan dengan kelas kontrol dengan DI. Sementara untuk BL juga menunjukkan hal yang sama, hasil menunjukkan bahwa kelas eksperimen dengan PMRI lebih tinggi sebesar 4,78 atau 18\% dibandingkan dengan kelas kontrol dengan DI.

Melalui pembelajaran PMRI siswa akan lebih melihat pembelajaran matematika sebagai usaha untuk memecahkan masalah dalam kehidupan sehari-hari sehingga memiliki motivasi yang lebih. Dengan dihadapkan pada suatu masalah, kemudian siswa diminta sendiri memecahkan masalah melakukan pencarian data dan eksperimentasi dalam rangka membuktikan kajian data yang mengarah pada penemuan konsep-konsep yang sedang dipelajari, dan lain-lain. Dalam setiap pembelajaran, siswa mendapat kesempatan untuk menggunakan pengetahuan yang dimiliki sebelumnya dan melatih keterampilan dan kemampuan berpikir. Kegiatan tersebut dapat dilakukan secara baik secara individu maupun kerjasama kelompok/ kelas. Melalui interaksi yang terjadi akan memberikan sebuah pengalaman yanag bermakna sehingga membantu perkembangan kognitif siswa (Schunk, 2008).

Dalam membelajarkan siswa untuk menguasai kompetensi matematika bukan pada banyaknya konsep yang harus dihapal, tetapi lebih kepada bagaimana agar siswa berlatih mengasah kemampuan berpikirnya untuk menemukan konsep-konsep matematis melalui pengalaman. Melalui pengalaman nyata ini siswa telah mempelajari keterampilan dan proses beripikir yang dilandasi oleh sikap keingintahuan untuk mentransformasi pengalaman nonformal menjadi pengalaman formal secara matematis. Dengan demikian siswa akan terlibat secara aktif dengan adanya interaksi. Hal ini sesuai dengan karakteristik RME yatu penggunaan masalah kontekstual, interaktivitas dan kontribusi siswa (Gravemeijer, 1994). 
Kegiatan lain dalam pembelajaran PMRI antara lain: Pertama, pembelajaran dilaksanakan dengan menyenangkan. Kegiatan pembelajaran dapat dilaksanakan baik didalam kelas maupun diluar kelas, dengan duduk di kursi ataupun dilantai. Hal ini menyebabkan siswa sangat antusias untuk mengikuti pembelajaran matematika. Kedua, pada kegiatan pembelajaran dengan PMRI guru memiliki peran sebagai pembimbing dan fasilitator. Dalam pembelajaran matematika dengan PMRI yang paling utama adalah memberikan kondisi yang seluasluasnya kepada siswa untuk memperoleh pengalaman untuk dapat membangun pengetahuan itu sendiri dan merepresentasikannya ke secara matematis. baik yang dilakukan secara individu maupun secara kelas.

Proses terpenting dalam pembelajaran dengan PMRI adalah proses matematisasi horizontal dan vertikal. Melalui matematisasi horizontal siswa dihadapkan dengan situasi nyata ataupun dengan hal yang kontekstual bagi siswa, kemudian mengembangkannya. Hal ini sesuai dengan teori Piaget (Schunk, 2008; Souviney, 1994; Byrnes, 2008) yang menyebutkan bahwa pada tahap konkret dimana untuk membelajarkan secara bermakna siswa perlu dihadapkan pada hal yang konkret ataupun nyata/kontekstual. Dari matematisasi horizontal tersebut berkembang menjadi matematisasi vertical/pengetahuan formal. Pada tahap ini siswa mulai berpikir untuk menggunakan representasi matemats seperti symbol dan angka sehingga siswa akan menemukan kembali dengan bantuan/ bimbingan. Hal ini sesuai dengan teori konstruktivis social Vygotsky dimana terjadi proses scaffolding. Dengan demikian melalui tahapan pembelajaran dalam PMRI tersebut siswa dapat menemukan model untuk menghubungkan/ menjembatani pengetahuan nonformal ke dalam pengetahuan formal. Hal ini sesuai dengan 3 prinsip RME yaitu guided reinvitation and progressing mathematizing, didactical phenomenology and self developed model (Gravemeijer, 1994).

Terkait dengan pembelajaran PMRI, keuntungan lain yang bisa didapat oleh siswa selain dapat memaksimalkan PK matematis adalah siswa memiliki kesempatan untuk mema-hami permasalahan dengan menghubungkan fakta-fakta yang ada dan menyusunnya dalam bentuk matematis. Kegiatan pembelajaran melalui PMRI memberikan rangsangan kepada siswa untuk selalu berpikir dan selalu mengembangkan kemampuan berpikirnya.
Berawal dari konteks nyata/objek disekitar akan mempermudah siswa untuk memahami suatu konsep. Proses ini mempermudah siswa dalam memahami dan dapat menjadi jembatan dalam pikiran siswa sendiri dari suatu konsep yang konkret menjadi konsep yang lebih abstrak. Disinilah proses berpikir siswa dilatih dimana siswa dapat mengaitkan pengetahuan yang telah diperolehnya untuk mempelajari pengetahuan baru sehingga akan lebih meningkatkan struktur kognitifnya. Dengan demikian pengetahuan baru akan terbentuk dalam proses berfikir dengan menyatukan pengetahuan-pengetahuan lama yang sudah dimiliki oleh siswa. Hal inilah yang dinamakan dengan pembelajaran bermakna (meaningfull learning) yang digagas oleh Ausubel. Pembelajaran semacam ini merangsang anak untuk melatih kemampuan berfikir sehingga akan membantu anak untuk berfikir logis. Hal inilah yang menyebabkan pendekatan PMRI memberikan hasil yang lebih tinggi daripada DI sehingga dapat dikatakan lebih berpengaruh positif bagi PK dan BL siswa.

Sementara itu hasil penelitian dari kelas kontrol dengan pembelajaran DI yang menunjukkan hasil yang lebih rendah daripada kelas eksperimen. Hal ini karena dalam pendekatan pembelajaran ini peran guru lebih dominan daripada keterlibatan siswa. Dalam pembelajaran model ini guru melaksanakan langkahlangkah pembelajaran sesuai dengan tahapantahapan yang sudah jelas. Kegiatan inti dalam pembelajaran lebih dominan diisi oleh transfer pnegetahuan oleh guru, jika dalam pembelajaran matematika guru memberikan rumus kemudian diikuti dengan latihan soal. Dengan demikian siswa diharapkan untuk menghafal rumusrumus dalam matematika sehingga dapat menggunakaannya untuk menyelesaikan soal matematika. Hal ini sesuai dengan 6 sintaks dalam pembelajaran DI yang disampaikan oleh Gunter (1990).

Kegiatan ini memaksa memahami konsep-konsep matematika langsung secara formal. Penyampaian konsep secara langsung dengan memberikan materi/ rumus untuk dapat digunakan secara langsung pula oleh siswa memberikan dampak waktu yang diperlukan cukup singkat. Hal selanjutnya dalam pembelajaran DI adalah dengan latihan soal sesering mungkin agar siswa benar-benar memahami konsep dengan benar. Pada kondisi dan siswa tertentu yang memiliki tingkat konsentrasi tinggi akan efektif untuk menerapkan konsep yang dipelajarinya, namun demikian hal ini hanya akan 
berlangsung singkat karena siswa kurang mengalami proses berpikir. Dengan demikian, proses belajar dengan model ini kurang melatih siswa untuk mengembangkan kemampuan berpikirnya terutama berpikir logis. Hal ini tentunya akan berakibat pada kemampuan siswa ketika dihadapkan pada suatu permasalahan yang kompleks.

Dalam pembelajaran model ini, apabila timbul keraguan maka dia bertanya hanya kepada guru padahal konsep-konsep dalam matematika tidak dapat dipahami secara langsung. Akibat pembelajaran DI, siswa tidak mendapat pengalaman untuk memahami konsep secara konkret, dan jika terdapat keragu-raguan dalam memahami konsep secara formal, siswa tidak akan bisa melakukan akomodasi dengan konsep-konsep yang bersifat konkret. Dalam pembelajaran model ini siswa tidak dilatih untuk mengembangkan kemampuan berpikirnya. Hal terpenting lainnya dalam pembelajaran DI adalah adanya reinforcement yaitu berupa penguatan-peguatan. Namun seringkali penguatan ini terlupakan oleh guru sehingga siswa merasa bahwa pembelajaran tidak menyenangkan. Hal ini tentunya juga menjadi salah satu faktor penyebab siswa kurang antusias terhadap pembelajaran matematika.

Berdasarkan uraian tahapan pembelajaran dan uraian hasil bukti empiris dilapangan bahwa PMRI dan DI memiliki kegiatan awal yang berbeda yaitu pada PMRI siswa dikondisikan dengan permasalahan yang kontekstual sementara DI langsung pada penyampaian materi. Hal tersebut tentunya berimbas pada kemampuan berpikir anak. Dari hasil analsisis data dan pembahasan tersebut diatas maka sesuailah dengan kerangka piker dan hipotesis yang diajukan sebelumnya bahwa PMRI memberikan pengaruh yang signifikan terhadap PK dan BL siswa. Kaitannya dengan hasil penelitian, bahwa dalam pembelajaran konsep perlu melatih dan mengembangkan kemampuan berpikir, sehingga pembelajaran yang dilakukan benar-benar bermakna. Hal ini tentunya dapat memberikan dampak bagi siswa untuk dapat terbiasa berpikir secara logis ketika mengahadapi permasalahan secara nyata dalam kehidupan sehari-hari. Namun demikian, perlu disadari bahwa tidak semua pokok bahasan dalam pelajaran matematika dapat diajarkan dengan pendekatan pembelajaran yang sama, terutama kaitannya dengan kompetensi matematika lainnya. Dengan demikian perlu pemilihan pendekatan ataupun model pembelajaran yang tepat bagi siswa sesuai dengan materi/pokok bahasan dengan tetap mengembangkan kemampuan berpikir siswa pada pelajaran matematika.

\section{Simpulan dan Saran}

Simpulan

Berdasarkan uji hipotesis dan pembahasan diperoleh kesimpulan sebagai berikut: Pertama, Pembelajaran PMRI memberikan pengaruh yang signifikan sebesar 0,000 terhadap pemahaman konsep dan berpikir logis siswa pada kelas eksperimen dengan PMRI daripada kelas kontrol dengan Direct Instruction.

Kedua, Terdapat pengaruh positif terhadap pemahaman konsep siswa pada kelas eksperimen dengan PMRI daripada kelas kontrol dengan Direct Instruction. Hal ini dibuktikan dengan hasil pengukuran yang diperoleh bahwa rata-rata skor pemahaman konsep siswa dengan PMRI lebih tinggi daripada rata-rata skor pemahaman konsep siswa dengan Direct Instruction.

Ketiga, Terdapat pengaruh positif terhadap kemampuan berpikir logis siswa pada kelas eksperimen dengan PMRI daripada kelas kontrol dengan Direct Instruction. Hal ini dibuktikan dengan hasil pengukuran yang diperoleh bahwa rata-rata skor berpikir logis siswa dengan PMRI lebih tinggi daripada ratarata skor berpikir logis siswa dengan Direct Instruction.

Saran

Berdasarkan kesimpulan penelitian dan memperhatikan keterbatasan penelitian, beberapa saran yang disampaikan sebagai berikut: Pertama, Guru kelas di SD sebaiknya melaksanakan pembelajaran matematika yang melibatkan siswa secara aktif seperti pembelajaran PMRI. Kedua, Guru kelas di SD sebaiknya melaksanakan pembelajaran matematika dengan PMRI untuk membantu siswa memahami konsep seperti jarak, waktu dan kecepatan. Ketiga, Guru kelas di SD sebaiknya melaksanakan pembelajaran matematika dengan PMRI untuk membantu siswa untuk melatih kemampuan berpikir seperti Berpikir Logis.

\section{Daftar Pustaka}

Bustang, et al., (2013). Developing a local instruction theory for learning the concept of angle through visual field activities and spatial representations. 
International Education Studies, 6, 5869

Byrnes, J.P. (2008). Cognitive development and learning (an instructional contexs). Boston: Pearson Allyn and Bacon

Depdiknas. (2003). UU No 20 Th 2003 tentang sistem pendidikan nasional.

Dickinson, P., \& Hough, S. (2012, Mei). Using realistic mathematics education in $U K$ classrooms. Artikel. Diambil pada tanggal 20 Maret 2014, dari http://www.mei.org.uk/files/pdf/RME_I mpact_booklet.pdf

Fathani, A.H. (2009). Matematika (hakekat dan logika). Yogyakarta: Ar Ruzz Media

Fauzan, A. (2002). Applying realistics mathematics education (rme) in theaching geometry in indonesian primary schools. Den Haag: CIPGegevens Koninklijke Bibliotheek

Fauzan, A., \& Yerizon. (2013). Pengaruh pendekatan RME dan kemandirian belajar terhadap kemampuan matematis siswa. Prosiding seminar FMIPA Universitas Lampung, 7-14

Gunter, M.A., Estes T.H., \& Schwab, J.H. (1990) Instruction: a model approach. London: Allyn and Bacon

Muchlis, E.E. (2012, Desember). Pengaruh PMRI terhadap kemampuan pemecahan masalah siswa kelas 2 SD kartika 1.10 Padang: Jurnal Exacta, X, 136-139

Nurhayati, A.N. \& Maulana. (2009, Oktober). Penerapan pendekatan matematika realistik dalam penananaman konsep perkalian dan pembagian bilangan bulat. Makalah disajikan dalam Konferensi Pendidikan Dasar I Tingkat Internasional, di Universitas Pendidikan Indonesia Kampus Sumedang

Rasmussen, C. et al., (2005). Advancing mathematical activity: a practiceoriented view of advanced mathematical thinking. Mathematical thinking and learning, 7, 51-73
Schunk, D. H. (2008). Learning theories, an educational perspective. fifth edition. New Jersey: Pearson Merril Prentice Hall

Sembiring, R.K., Hadi, S., \& Dolk, M. (2008). Reforming mathematics learning in indonesian classrooms through RME. ZDM Mathematics Education, 40, 927939

Somakin. (2011, Januari). Peningkatan kemampuan berpikir kritis matematis siswa SMP dengan PMRI. Forum MIPA, 14, 42-49

Souviney, R.J. (1994). Learning to teach mathematics. New York: Macmillan Publishing Company

Sugiman \& Kusuma, Y.S. (2010, Juli). Dampak pendidikan matematika realistik terhadap peningkatan kemampuan pemecahan masalah siswa SMP. IndoMS Journal Mathematics Educations, 1, 41-51

Supinah. (2008). Modul pembelajaran matematika sd dengan pendekatan kontekstual dalam melaksanakan KTSP. Yogyakarta: P4TK matematika.

Tjalla, A. (2010). Potret mutu pendidikan indonesia ditinjau dari hasil- hasil studi internasional. Diambil pada tanggal 10 Mei 2013, dari www.pustaka.ut.ac.id/dev25/pdfprosidi ng2/fkip201047.pdf

Van Den Heuvel, M., \& Panhuizen. (1996). Asessment and realistic mathematics education. Utrech: CD-B Press, Center for Science and Mathematics Education

Zandieh, M. \& Rasmussen, C. (2010). Defining as a mathematical activity: a framework for characterizing progress from informal to more formal ways of reasonng. Journal of Mathematics Behavior, 229, 57-75

Zulkardi. (2002). Developing a learning environment on realistic mathematics education for Indonesian student teacher. Den Haag: CIP-Gegevens Koninklijke Bibliotheek 